\title{
Zmiany w systemie gospodarki odpadami komunalnymi - aspekty prawne i ekonomiczne na przykładzie m.st. Warszawy
}

\author{
Anna Wieczorek, Maciej Siekierski
}

\section{STRESZCZENIE}

Autorzy artykułu uważają że: należy zrezygnować ze zbyt skomplikowanych metod ustalania stawek opłaty za gospodarowanie odpadami komunalnymi, przyjętych w ustawie o utrzymaniu czystości i porządku w gminach; najprostszym i najbardziej sprawiedliwym byłoby wprowadzenie jednej opłaty od każdej osoby, deklarującej miejsce zamieszkania na terenie Polski, a ww. opłatę można powiązać np. z podatkiem dochodowym.

Takie rozwiązanie zlikwidowałoby spory, dotyczące tego, kto gdzie mieszka, ile ma nieruchomości oraz co oznaczają takie pojęcia jak: zamieszkują mieszkańcy czy domek letniskowy; kto i ile wody zużywa oraz jak to szacować; jak ustalać powierzchnie lokali.

Na przykładzie Warszawy wykazano, że obowiązujący od dnia 01.03.2020 r. system gospodarowania odpadami komunalnymi, determinowany ustawą o utrzymaniu czystości i porządku w gminach jest mało precyzyjny - w wielu sytuacjach nie wiadomo jak naliczać opłaty; jest krzywdzący dla jednoosobowych gospodarstw domowych, których znaczącą liczbę stanowią emeryci i renciści.

Słowa kluczowe: odpady komunalne, zasady gospodarowania odpadami komunalnymi, wysokość opłat, gospodarstwo domowe, miejsce zamieszkania

\section{Wprowadzenie}

Odpady, potocznie zwane śmieciami, towarzyszą ludziom od zawsze. Archeolodzy na ich podstawie potrafią określić jak wyglądało życie przed tysiącami lat. Współcześnie wiele dziedzin nauki zajmuje się odpadami, od szeroko rozumianej problematyki ochrony środowiska, planowania przestrzennego i budownictwa, do ekonomii, edukacji i prawa.

„Odpady są wytworem człowieka i stanowią formę nieprzydatną w miejscu i czasie ich powstawania; są to uciążliwe dla środowiska, zużyte i nie spożytkowane produkty bytowe oraz gospodarcze naszej działalności. Konieczność unieszkodliwiania odpadów stałych, podobnie jak problemy emisji zanieczyszczeń do atmosfery i wód, zanieczyszczania gleby oraz niszczenia różnorodności biologicznej, stanowi podstawowe zagadnienie współczesnej ochrony środowiska." [Karaczun, Indeka 1996, s. 183].

„Każda gospodarcza działalność człowieka łączy się obecnie w sposób nierozerwalny z produkowaniem odpadów. Rozwiązaniem idealnym, niemożliwym do zastosowania na większą skalę, ani teraz, ani w najbliższej przyszłości, jest stosowanie technologii bezod- 
padowych. Takie technologie stosowane są powszechnie w świecie przyrody. (...) Należy mocno podkreślić, że brak jest jasnej i jednoznacznej definicji odpadów. Każda materia czy substancja pozyskiwana, przetwarzana i przemieszczana przez człowieka, może być zasobem i produktem użytecznym lub też odpadem. Każdy niezagospodarowany i niemający swojego określonego przeznaczenia produkt (surowiec, materiał) nabywa właściwości odpadu. I odwrotnie - każdy odpad staje się surowcem lub materiałem z chwilą jego zagospodarowania." [Nowicki 1993, s. 129].

Świadomość zagrożenia środowiska powodowanego przez człowieka, skłania do podjęcia kompleksowych działań, zarówno w skali światowej jak i poszczególnych państw, mających na celu zapobieganie niszczeniu przyrody, np. poprzez ograniczenie do minimum powstawania odpadów. Skoro ludzie, jak do tej pory nie wymyślili technologii bezodpadowych, to przynajmniej powinni podjąć próby zagospodarowania tego, co da się ponownie wykorzystać.

W tym miejscu warto przywołać pojęcie quasi-bezodpadowej gospodarki w obiegu zamkniętym, w której odpady są co prawda wytwarzane, ale cały ich strumień po jego odpowiednim przetworzeniu jest zawracany jako surowiec do odpowiednich, powiązanych z takim typem gospodarki procesów przemysłowych. Mówi się wyraźnie o odejściu od gospodarki linearnej i rządzącej nią zasady „weź - wyprodukuj - zużyj - wyrzuć”. W konsekwencji odpady powinny przestać być traktowane jako ostatni etap cyklu życia powiązanych z nimi produktów. Przyjęty w 2019 r. przez Radę Ministrów Rzeczypospolitej Polskiej dokument p.t. Mapa Drogowa Transformacji w kierunku gospodarki o obiegu zamkniętym określa narzędzia, w tym prawne, których celem jest stworzenie korzystnych warunków do wdrożenia w Polsce tego nowego modelu gospodarowania.

Pożądane postępowanie człowieka można stymulować w różny sposób - poprzez odpowiednią edukację, regulacje prawne - nakazy, zakazy albo zachęty ekonomiczne.

Aby ludzie zrozumieli, że ochrona środowiska, w tym racjonalne postępowanie z odpadami może im służyć, niezbędna jest edukacja, prowadzona w poszczególnych państwach oraz w skali globalnej, np. przez Unię Europejską i inne organizacje o znaczeniu międzynarodowym. „Trwałe pojawienie się problematyki środowiskowej datuje się od wystąpienia sekretarza generalnego ONZ, U Thanta, w 1969 r. Szczególną aktywność przejawił w tej mierze organ ONZ - UNESCO, podejmując szereg uchwał na rzecz rozwoju edukacji ekologicznej, stanowiących wytyczne i zobowiązania do rozwijania narodowych programów edukacji środowiskowej, jako niezwykle istotnego składnika ogólnego systemu oświaty."[Małachowski, Jacyna, Szulczewski 1994, s. 21].

Wspólnota Europejska, a obecnie Unia Europejska od lat wydaje szereg aktów prawa dotyczących szeroko rozumianej ochrony środowiska. „Od roku 1975 weszło w życie kilka zasad Wspólnoty w zakresie gromadzenia, składowania, przerobu i przetwarzania odpadów, których Unia Europejska produkuje każdego roku ponad 2 mld ton. Specjalnymi przepisami objęto także odpady produkowane przez przemysł tlenku tytanu, zużyty olej, odprowadzanie zanieczyszczeń do morza i odpady radioaktywne. Sformułowano też zalecenia w sprawie ponownego wykorzystania starego papieru, tektury i pojemników po napojach." [Leonard 2003, s. 249]. 
Jeśli przyjąć, że każdy surowiec i materiał może być odpadem lub czymś pożytecznym, to konsekwencją takiego rozumowania jest doprowadzenie do tego, aby jak najwięcej odpadów wykorzystać ponownie. Tak narodził się pomysł segregacji śmieci i ich ponownego wykorzystywania, w tym opakowań wielokrotnego użytku.

Zbieranie i segregowanie odpadów powinno się opłacać. Jeśli zabraknie zachęty ekonomicznej, to szczytne ideały dbania o czystość naszej planety pozostaną tylko teoria a nakazy i zakazy wynikające z przepisów prawa będą omijane. „Z ekonomicznego punktu widzenia segregacja odpadów wymagała poczynienia sporych nakładów przez osoby segregujące odpady w postaci zakupu różnorodnych pojemników przeznaczonych do segregacji oraz wygospodarowania odpowiedniego miejsca do gromadzenia odpadów w czasie między wyrzuceniem a odbiorem. W niektórych przypadkach wiązało się to również z większym zużyciem wody i energii, gdyż osoby przechowujące odpady w domu lub mieszkaniu myły je w celu utrzymania czystości w pomieszczeniach mieszkalnych. Choć z punktu widzenia ustawodawcy koszty te mogą wydawać się znikome, dla osób posiadających niskie zarobki, zamieszkujących mniejsze miasta i wsie, koszty te obniżałyby bieżącą konsumpcję." [Żurawiecka, Kocia 2019, s. 47 i 48]. Jak z powyższego wynika, segregacja odpadów nie dla każdego jest opłacalna.

Polski system prawny nakłada obowiązek selektywnego zbierania odpadów komunalnych: papier, szkło, metale i tworzywa sztuczne oraz odpady ulegające biodegradacji. Aby prawo było przestrzegane, bez konieczności stosowania środków represji (kar) niezbędne są odpowiednie bodźce ekonomiczne oraz świadomość, że segregacja chroni środowisko, a tym samym zdrowie ludzi.

Kluczowe znaczenie mają tu opłaty za gospodarowanie odpadami komunalnymi, które muszą uwzględniać możliwości finansowe mieszkańców i być uznane za sprawiedliwe. Oznacza to, że żadnej grupy społecznej nie można nimi nadmiernie obciążać.

Artykuł dotyczy polskiego systemu ustalania opłat za gospodarowanie odpadami komunalnymi. Na przykładzie uchwał podjętych przez Radę m.st. Warszawy wykazano, jak bardzo ww. system jest niedoskonały. Zasugerowano zmiany prawa, które w odczuciu społecznym można uznać za sprawiedliwe i powszechnie zrozumiałe.

\section{Wybrane zagadnienia dotyczące utrzymania czystości na terenach polskich miast i wsi}

\section{Akty prawa}

Podstawowymi przepisami regulującymi zagadnienia dotyczące utrzymania czystości na terenach polskich miast i wsi są: ustawa o odpadach (uod) oraz ustawa o utrzymaniu czystości i porządku w gminach (ucz), która jest podstawą do wydawania przez gminy aktów prawa miejscowego dotyczących odpadów komunalnych. Obydwie ustawy dokonują w zakresie swojej regulacji wdrożenia dyrektyw Unii Europejskiej [Kiepas-Kokot 2017a,b; Mostowska, Budziński, Wilczyńska 2014; Niewiadomski 2019]. 


\section{Regulamin utrzymania czystości i porządku na terenie gminy}

Utrzymanie czystości i porządku należy do zadań własnych gminy [art. 3 ust. 1 ucz]. Rada gminy uchwala regulamin utrzymania czystości i porządku na terenie gminy, który jest aktem prawa miejscowego [art. 4 ust. 1 ucz]. Regulamin dotyczy:

1) odpadów komunalnych, w tym selektywnego ich zbierania i odbierania;

2) częstotliwości i sposobu pozbywania się nieczystości ciekłych;

3) sprzątania błota, śniegu, lodu i innych zanieczyszczeń z nieruchomości lub ich części, służących do użytku publicznego;

4) mycia i naprawy pojazdów samochodowych poza myjniami i warsztatami;

5) zwierząt domowych oraz zwierząt gospodarskich, w tym zakazu ich utrzymywania na określonych obszarach;

6) obszarów podlegających obowiązkowej deratyzacji;

7) utrzymania w odpowiednim stanie sanitarnym miejsc gromadzenia odpadów [art. 4 ust. 2 ucz].

Ponadto rada gminy może w ww. regulaminie „określić wymagania dotyczące kompostowania bioodpadów stanowiących odpady komunalne w kompostownikach przydomowych na terenie nieruchomości zabudowanych budynkami mieszkalnymi jednorodzinnymi oraz zwolnić właścicieli takich nieruchomości, w całości lub w części, z obowiązku posiadania pojemnika lub worka na te odpady" [art. 4 ust. 2a pkt 4 ucz.].

\section{Recykling, odzysk oraz odzysk energii}

Gminy są obowiązane osiągnąć poziom recyklingu odpadów komunalnych w wysokości co najmniej:

- $\quad 50 \%$ wagowo - za każdy rok w latach 2020-2024;

- 55\% wagowo - za każdy rok w latach 2025-2029;

- $\quad 60 \%$ wagowo - za każdy rok w latach 2030-2034;

- $\quad 65 \%$ wagowo - za 2035 r. i za każdy kolejny rok. [art. 3b ust. 1 pkt 1, 2, 3 i 4 ucz].

„Gminy są obowiązane ograniczyć masę odpadów komunalnych ulegających biodegradacji przekazywanych do składowania (...) do dnia 16 lipca 2020 r. - do nie więcej niż 35\% wagowo całkowitej masy odpadów komunalnych ulegających biodegradacji przekazywanych do składowania - w stosunku do masy tych odpadów wytworzonych w 1995 r." [art. 3 c ust. 1 pkt 2 ucz].

W polskim systemie prawnym występują pojęcia: recykling, odzysk oraz odzysk energii.

Pod pojęciem recyklingu rozumie się „odzysk, w ramach którego odpady są ponownie przetwarzane na produkty, materiały lub substancje wykorzystywane w pierwotnym celu lub innych celach; obejmuje to ponowne przetwarzanie materiału organicznego (recykling organiczny), ale nie obejmuje odzysku energii i ponownego przetwarzania na materiały, które mają być wykorzystane jako paliwa lub do celów wypełniania wyrobisk" [art. 3 ust. 1 pkt 23 uod]. 
Oznacza to, że te same, postrzegane jako uciążliwość i zagrożenie odpady, mogą być mniej lub bardziej efektywnie poddawane procesom przetwarzania. W zależności od rodzaju odpadu możliwe jest odzyskanie surowców do powtórnej produkcji analogicznych wyrobów (opakowania szklane, butelki PET itp.), substratów dla przemysłu metalurgicznego (odpady metali, ale także elektrośmieci), nawozów organicznych (kompostowanie bioodpadów).

Pod pojęciem odzysku - rozumie się , jakikolwiek proces, którego głównym wynikiem jest to, aby odpady służyły użytecznemu zastosowaniu przez zastąpienie innych materiałów, które w przeciwnym przypadku zostałyby użyte do spełnienia danej funkcji, lub w wyniku którego odpady są przygotowywane do spełnienia takiej funkcji w danym zakładzie lub ogólnie w gospodarce" [art. 3 ust. 1 pkt 14 uod].

Pod pojęciem odzysku energii - rozumie się „termiczne przekształcanie odpadów w celu odzyskania energii" [art. 3 ust. 1 pkt 15 uod].

Z powyższego wynika, że do recyklingu ustawodawca (idąc w tej mierze za regulacjami tworzonymi na poziomie Unii Europejskiej) nie włączył procesów pozwalających na odzyskiwanie zawartej w odpadach energii. Dotyczy to zarówno odzysku o charakterze bezpośrednim - spalanie odpadów, jak też i pośrednim - piroliza.

\section{Zasady odbierania odpadów komunalnych od właścicieli nieruchomości}

Gminy mają obowiązek „zorganizowania odbierania odpadów komunalnych od właścicieli nieruchomości, na których zamieszkują mieszkańcy” [art. 6c ust. 1 ucz]. Mogą również zorganizować odbieranie „odpadów komunalnych od właścicieli nieruchomości, na których nie zamieszkują mieszkańcy, a powstają odpady komunalne” [art. 6c ust. 2 ucz].

Przystąpienie właścicieli nieruchomości, na których nie zamieszkują mieszkańcy, do gminnego systemu gospodarowania odpadami jest dobrowolne [art. $6 \mathrm{c}$ ust. 2c ucz]. Wyjątek stanowią właściciele domków letniskowych lub „innej nieruchomości wykorzystywanej na cele rekreacyjno-wypoczynkowe" [art. 6c ust. 2c w związku z art. 6j ust. 3b ucz], którzy muszą przystąpić do zorganizowanego przez gminę systemu odbierania odpadów komunalnych.

\section{Obowiązki właścicieli nieruchomości, w tym obowiązek ponoszenia opłaty za gospodarowa- nie odpadami komunalnymi}

Właściciele są zobowiązani do utrzymania czystości i porządku w swoich nieruchomościach. W odniesieniu do odpadów komunalnych mają obowiązek zbierania ich w sposób selektywny oraz pozbywanie się ich w sposób zgodny z przepisami prawa [art. 5 ust. 1 ucz]. „Właściciele nieruchomości (...) są obowiązani ponosić na rzecz gminy, na terenie której są położone ich nieruchomości, opłatę za gospodarowanie odpadami komunalnymi." [art. 6h ucz]. Obowiązek ponoszenia opłaty za gospodarowanie odpadami komunalnymi powstaje:

1) „w przypadku nieruchomości, na której zamieszkują mieszkańcy - za każdy miesiąc, 
w którym na danej nieruchomości zamieszkuje mieszkaniec" [art. 6i ust. 1 pkt 1 ucz];

2) „W przypadku nieruchomości, na której nie zamieszkują mieszkańcy - za każdy miesiąc, w którym na danej nieruchomości powstały odpady komunalne" [art. 6i ust. 1 pkt 2 ucz], przy czym, jak już napisano, przystąpienie do zorganizowanego przez gminę systemu gospodarowania odpadami komunalnymi jest dobrowolne [art. $6 \mathrm{c}$ ust. 2c ucz];

3) „w przypadku nieruchomości, na której znajduje się domek letniskowy i innej nieruchomości wykorzystywanej na cele rekreacyjno-wypoczynkowe - za rok bez względu na długość okresu korzystania z nieruchomości" [art. 6i ust. 1 pkt 3 ucz].

Właściciele nieruchomości, którzy nie są obowiązani do ponoszenia opłat za gospodarowanie odpadami komunalnymi na rzecz gminy, bo nie przystąpili do zorganizowanego przez gminę systemu gospodarowania odpadami komunalnymi, są obowiązani do udokumentowania korzystania z usług wykonywanych przez gminną jednostkę organizacyjną lub przedsiębiorcę odbierającego odpady komunalne wpisanego do stosownego rejestru działalności [art. 6 ust. 1 i ust. 1 a ucz].

\section{Metody ustalenia opłaty za gospodarowanie odpadami komunalnymi}

Rada gminy, w drodze uchwały:

1) dokonuje wyboru metody ustalenia opłaty za gospodarowanie odpadami komunalnymi spośród metod określonych w ustawie o utrzymaniu czystości i porządku w gminach oraz ustala stawkę takiej opłaty [art. 6k ust. 1 pkt 1 ucz];

2) „ustali stawkę opłaty za pojemnik lub worek o określonej pojemności, przeznaczony do zbierania odpadów komunalnych na terenie nieruchomości" [art. 6k ust. 1 pkt 2 ucz].

W przypadku nieruchomości, na której zamieszkują mieszkańcy, „opłata za gospodarowanie odpadami komunalnymi stanowi iloczyn:

1) liczby mieszkańców zamieszkujących daną nieruchomość lub

2) ilości zużytej wody z danej nieruchomości lub

3) powierzchni lokalu mieszkalnego - oraz stawki opłaty" [art. 6j ust. $1 \mathrm{ucz}$ ].

„W przypadku nieruchomości, na której zamieszkują mieszkańcy, rada gminy może uchwalić jedną stawkę opłaty za gospodarowanie odpadami komunalnymi od gospodarstwa domowego." [art. 6j ust. 2 ucz].

Rada gminy ustala stawki opłat w wysokości nie wyższej niż maksymalne stawki opłat, które za odpady komunalne zbierane i odbierane w sposób selektywny wynoszą za miesiąc: 1) w przypadku, gdy opłata zależy od liczby mieszkańców zamieszkujących daną nieruchomość - „2\% przeciętnego miesięcznego dochodu rozporządzalnego na 1 osobę ogółem - za mieszkańca" [art. 6j ust. 1 pkt 1 w związku z art. 6k ust. 2a pkt 1 ucz], co wynosiło:
a) w 2019 r. - 33,86 zł x liczba mieszkańców,
b) w 2020 r. - 36,38 zł x liczba mieszkańców; 
2) w przypadku, gdy opłata zależy od ilości zużytej wody z danej nieruchomości - „0,7\% przeciętnego miesięcznego dochodu rozporządzalnego na 1 osobę ogółem - za $\mathrm{m}^{3}$ zużytej wody" [art. 6j ust. 1 pkt 2 w związku z art. 6k ust. 2a pkt 2 ucz], co wynosiło:

a) w 2019 r. - 11,851 zł x liczbę $\mathrm{m}^{3}$ wody,

b) w 2020 r. - 12,733 zł x liczbę $\mathrm{m}^{3}$ wody;

3) w przypadku, gdy opłata zależy od powierzchni lokalu mieszkalnego - „0,08\% przeciętnego miesięcznego dochodu rozporządzalnego na 1 osobę ogółem za $\mathrm{m}^{2}$ powierzchni lokalu mieszkalnego" [art. 6j ust. 1 pkt 3 w związku z art. 6k ust. 2a pkt 3 ucz], co wynosiło:

a) w 2019 r. - 1,3544 zł. x liczba $\mathrm{m}^{2}$ powierzchni,

b) w 2020 r. - 1,4552 zł. x liczba $\mathrm{m}^{2}$ powierzchni;

4) w przypadku nieruchomości, na której zamieszkują mieszkańcy i uchwala się jedną stawkę - „5,6\% przeciętnego miesięcznego dochodu rozporządzalnego na 1 osobę ogółem - za gospodarstwo domowe" [art. 6j ust. 2 w związku z art. 6k ust. 2a pkt 4 ucz], co wynosiło:

a) w 2019 r. $-94,808 \mathrm{zl}$,

b) w 2020 r. - 101,864 zł;

5) „w przypadku nieruchomości, na której nie zamieszkują mieszkańcy - 3,2\% przeciętnego miesięcznego dochodu rozporządzalnego na 1 osobę ogółem za pojemnik o pojemności 1100 litrów lub 1\% przeciętnego miesięcznego dochodu rozporządzalnego na 1 osobę ogółem za worek o pojemności 120 litrów, przeznaczone do zbierania odpadów komunalnych na terenie nieruchomości; za pojemniki lub worki o mniejszej lub większej pojemności stawki opłat ustala się w wysokości proporcjonalnej do ich pojemności" [art. 6j ust. $3 \mathrm{w}$ związku z art. 6k ust. 2a pkt 5], co wynosiło za worek o pojemności 120 litrów:

a) w 2019 r. $-16,93 \mathrm{zt}$,

b) w 2020 r. - 18,19 zł;

6) w przypadku „nieruchomości, na której znajduje się domek letniskowy, lub innej nieruchomości wykorzystywanej na cele rekreacyjno-wypoczynkowe, rada gminy uchwala ryczałtową stawkę opłaty za gospodarowanie odpadami komunalnymi nie wyższą niż $10 \%$ przeciętnego miesięcznego dochodu rozporządzalnego na 1 osobę ogółem - za rok" [art. 6c ust. 2c w związku z art. 6j ust. 3b ucz], co wynosiło:

a) w 2019 r. $-169,30 \mathrm{zt}$,

b) w 2020 r. - 181,90 zł.

Przeciętny miesięczny dochód rozporządzalny na 1 osobę ogłasza corocznie Prezes Głównego Urzędu Statystycznego, wydając stosowne obwieszczenie. W 2019 r. ww. dochód wynosił 1693 zł, w 2020 r. - 1819 zł. 


\section{Odpady komunalne w Warszawie}

\section{Podstawowe ustalenia uchwał Rady m.st. Warszawy dotyczące wysokości opłat}

W dniu 01.03.2020 r. zmieniły się zasady gospodarowania odpadami komunalnymi w Warszawie, co skutkuje zmianą opłat i koniecznością złożenia nowych deklaracji. Informuje o tym Obwieszczenie Prezydenta m.st. Warszawy (nie znaleziono daty jego wydania). W powyższym Obwieszczeniu powołano się na sześć uchwał Rady m.st. Warszawy, podjętych w grudniu 2019 r. oraz w styczniu $2020 \mathrm{r}$.

Najistotniejsza z ww. uchwał, to uchwała nr XXIV/671/2019 w sprawie wyboru metody ustalania opłat za gospodarowanie odpadami komunalnymi i stawek opłaty oraz zmieniająca ją uchwała nr XXV/728/2020.

Dla zachowania precyzji wypowiedzi przepis $\S 1$ ust. 1 i ust. 2 ww. uchwały nr XXIV/671/2019 przytoczono poniżej w formie cytatu.

„1. Dokonuje się wyboru metody ustalania opłaty za gospodarowanie odpadami komunalnymi od gospodarstwa domowego:

1) dla nieruchomości, na której zamieszkują mieszkańcy, zabudowanej budynkiem mieszkalnym jednorodzinnym (...);

2) dla nieruchomości, na której zamieszkują mieszkańcy, zabudowanej budynkiem mieszkalnym wielolokalowym.

2. Ustala się stawki opłat od gospodarstwa domowego:

1) dla nieruchomości, o której mowa w ust. 1 pkt 1 w wysokości 94,00 zł;

2) dla nieruchomości, o której mowa w ust. 1 pkt 2 w wysokości 65,00 zł."

Należy domniemywać, że chodzi o opłaty za jeden miesiąc - brakuje takiego ustalenia w omawianej uchwale.

Przepis § 1 ww. uchwały:

1) ustala stawki opłat od gospodarstwa domowego, bez względu na liczbę osób tworzących ww. gospodarstwo, a różnicuje je w zależności od tego, czy gospodarstwo domowe zamieszkuje:

a) budynek mieszkalny jednorodzinny,

b) budynek mieszkalny wielolokalowy;

2) nie uzależnia stawek opłat od tego ile nieruchomości / lokali jest własnością gospodarstwa domowego.

Stawki opłat 94 zł i 65 zł:

1) dotyczą wyłącznie nieruchomości, będącej miejscem zamieszkania gospodarstwa domowego;

2) nie dotyczą nieruchomości, której właścicielem jest gospodarstwo domowe, ale w niej nie mieszka.

Przepisy kolejnych paragrafów uchwały nr XXIV/671/2019 dotyczą nieruchomości, nie będących niczyim miejscem zamieszkania:

1) za nieruchomości, na których nie zamieszkują mieszkańcy, a powstają odpady komu- 
nalne ustala się stawki opłat uzależnione od pojemności pojemnika / worka i liczby pojemników / worków w miesiącu, np. za pojemnik o pojemności $1201-5,90$ zł, a za worek o tej samej pojemności - 16,93 zł. [§3];

2) za domek letniskowy lub inną nieruchomość wykorzystywaną na cele rekreacyjno-wypoczynkowe, ustalono ryczałtową stawkę - 169,30 zł za rok [§ 4].

Ponad to obowiązują:

- uchwała nr XXIV/676/2019 oraz zmieniająca ją uchwała nr XXV/730/2020;

- uchwała nr XXIV/672/2019;

- uchwała nr XXV/731/2020.

Wszystkie ww. uchwały podjęto na podstawie ustawy o utrzymaniu czystości i porządku w gminach. Załącznik do niniejszego artykułu zawiera pełne nazwy i daty ww. uchwał oraz wykaz artykułów, będących podstawą ich podjęcia.

\section{Definicje}

W omawianych uchwałach Rady m.st. Warszawy brakuje definicji szeregu pojęć, które są niejednoznaczne, a rzutują na wysokość opłat. $W$ takiej sytuacji, nie pozostaje nic innego, jak posłużyć się definicjami zawartymi w ustawie o utrzymaniu czystości i porządku w gminach, a jeśli ich tam nie ma, w powszechnie obowiązujących przepisach prawa regulujących daną dziedzinę życia, w normach lub literaturze przedmiotu. Poniżej omówiono pojęcia, które uznano za najistotniejsze.

\section{Odpady}

Brak definicji tego pojęcia w ww. uchwałach. W ustawie o utrzymaniu czystości i porządku w gminach zastosowano odesłanie do ustawy o odpadach [art. 1a ucz].

Odpady, to każda substancja lub przedmiot, „których posiadacz pozbywa się, zamierza się pozbyć lub do których pozbycia się jest obowiązany" [art. 3 ust. 1 pkt 6 uod].

Odpady komunalne, to „odpady powstające w gospodarstwach domowych, z wyłączeniem pojazdów wycofanych z eksploatacji, a także odpady niezawierające odpadów niebezpiecznych pochodzące od innych wytwórców odpadów, które ze względu na swój charakter lub skład są podobne do odpadów powstających w gospodarstwach domowych; niesegregowane (zmieszane) odpady komunalne pozostają niesegregowanymi (zmieszanymi) odpadami komunalnymi, nawet jeżeli zostały poddane czynności przetwarzania odpadów, która nie zmieniła w sposób znaczący ich właściwości" [art. 3 ust. 1 pkt 7 uod].

Bioodpady, to „ulegające biodegradacji odpady z ogrodów i parków, odpady spożywcze i kuchenne z gospodarstw domowych, gastronomii, zakładów zbiorowego żywienia, jednostek handlu detalicznego, a także porównywalne odpady z zakładów produkujących lub wprowadzających do obrotu żywność" [art. 3ust. 1 pkt 1 uod]. Jak napisano we Wprowadzeniu, w literaturze przedmiotu pojęcie odpady jest różnie definiowane. 


\section{Gospodarowanie odpadami komunalnymi}

Brak definicji tego pojęcia w ww. uchwałach. W ustawie o utrzymaniu czystości i porządku w gminach zastosowano odesłanie do ustawy o odpadach [art. 1a ucz].

Gospodarowanie odpadami, to „zbieranie, transport, przetwarzanie odpadów, łącznie z nadzorem nad tego rodzaju działaniami, jak również późniejsze postępowanie z miejscami unieszkodliwiania odpadów oraz działania wykonywane w charakterze sprzedawcy odpadów lub pośrednika w obrocie odpadami" [art. 3 ust. 1 pkt 2 uod].

\section{Gospodarka odpadami}

Gospodarka odpadami, to „wytwarzanie odpadów i gospodarowanie odpadami” [art. 3 ust. 1 pkt 3 uod].

\section{Gospodarstwo domowe}

Brak definicji tego pojęcia w ww. uchwałach oraz w ustawie o utrzymaniu czystości i porządku w gminach.

Obwieszczenie Prezydenta m.st. Warszawy odsyła do definicji zawartej w ustawie z dnia 21 czerwca 2001 r. o dodatkach mieszkaniowych. „Przez gospodarstwo domowe rozumie się gospodarstwo prowadzone przez osobę ubiegającą się o dodatek mieszkaniowy, samodzielnie zajmującą lokal albo gospodarstwo prowadzone przez tę osobę wspólnie z małżonkiem i innymi osobami stale z nią zamieszkującymi i gospodarującymi, które swoje prawa do zamieszkiwania w lokalu wywodzą z prawa tej osoby." [art. 4].

Definicja wysoce niefortunna - zapewne większość gospodarstw, o których mowa w ww. uchwałach, nie ubiega się o dodatki mieszkaniowe.

Według Głównego Urzędu Statystycznego „gospodarstwo domowe to zespół osób zamieszkujących razem i wspólnie utrzymujących się", przy czym odrębne gospodarstwa domowe stanowią „,członkowie rodzin mieszkających wspólnie, ale utrzymujących się oddzielnie" [GUS 2020].

Wikipedia określa gospodarstwo domowe w poniższy sposób:

"Gospodarstwo domowe - w naukach ekonomicznych definiuje się jako podstawową jednostkę gospodarująca, której celem jest zaspokojenie wspólnych i osobistych potrzeb jego członków. Jest to jednostka ekonomiczna o walorach społecznych, zgłaszających zapotrzebowanie na dobra i usługi." [Wikipedia 2020].

„Gospodarstwo domowe to autonomiczna jednostka ekonomiczna, trwale uprawiająca działalność. To zarówno jednoosobowy, jak i wieloosobowy zespół osób spokrewnionych lub niespokrewnionych, wspólnie utrzymujących się i podejmujących decyzje o zagospodarowaniu środków w części lub w całości wniesionych do budżetu domowego. Jedną z ka- 
tegorii wyróżniających gospodarstwo domowe jest mieszkanie - gospodarstwo domowe to zespół osób zamieszkujących jedno mieszkanie." [Wikipedia 2020].

\section{Właściciele nieruchomości}

Brak definicji tego pojęcia w ww. uchwałach. Ustawa o utrzymaniu czystości i porządku w gminach, stanowi, że pod pojęciem właściciel nieruchomości rozumie się także „współwłaścicieli, użytkowników wieczystych oraz jednostki organizacyjne i osoby posiadające nieruchomości w zarządzie lub użytkowaniu, a także inne podmioty władające nieruchomością" [art. 2 ust. 1 pkt 4 ucz].

Definicja niezwykle pojemna, może prowadzić do tego, że pod pojęciem właściciel będzie się rozumiało również lokatora.

\section{Nieruchomość, na której zamieszkują mieszkańcy}

Brak definicji tego pojęcia w ww. uchwałach oraz w ustawie o utrzymaniu czystości i porządku w gminach.

Kodeks cywilny stanowi, że:

„Miejscem zamieszkania osoby fizycznej jest miejscowość, w której osoba ta przebywa z zamiarem stałego pobytu." [art. $25 \mathrm{Kc}$ ].

„Można mieć tylko jedno miejsce zamieszkania." [art. 28 Kc].

„Nieruchomościami są części powierzchni ziemskiej stanowiące odrębny przedmiot własności (grunty), jak również budynki trwale z gruntem związane lub części takich budynków, jeżeli na mocy przepisów szczególnych stanowią odrębny od gruntu przedmiot własności." [art. $46 \S 1 \mathrm{Kc}$ ].

Pojęcie nieruchomość ma kilka definicji w polskim systemie prawnym. Wydaje się, że należy stosować definicję z Kodeksu cywilnego, bo tylko Kodeks cywilny definiuje jednocześnie pojęcie nieruchomość i pojęcie miejsce zamieszkania.

\section{Nieruchomość, na której nie zamieszkują mieszkańcy}

Brak definicji tego pojęcia w ww. uchwałach. Z ustawy o utrzymaniu czystości i porządku w gminach wynika jedynie, że obiekty budowlane w rodzinnych ogrodach działkowych, są traktowane jako nieruchomości, na których nie zamieszkują mieszkańcy [art. 6j ust. 3 i 3d ucz]. Nie znaleziono definicji w innych przepisach prawa. 


\section{Budynek mieszkalny jednorodzinny}

W uchwale nr XXIV/671/2019 zastosowano odesłanie do definicji zawartej w art. 3 pkt 2a ustawy Prawo budowlane z 1994 r. Budynek mieszkalny jednorodzinny, to „,budynek wolno stojący albo budynek w zabudowie bliźniaczej, szeregowej lub grupowej, służący zaspokajaniu potrzeb mieszkaniowych, stanowiący konstrukcyjnie samodzielną całość, w którym dopuszcza się wydzielenie nie więcej niż dwóch lokali mieszkalnych albo jednego lokalu mieszkalnego i lokalu użytkowego o powierzchni całkowitej nieprzekraczającej $30 \%$ powierzchni całkowitej budynku" [art. 3 pkt 2a]. Podkreślenia wymaga, że ww. budynek może być jednym lub dwoma lokalami.

\section{Budynek mieszkalny wielolokalowy}

Brak definicji tego pojęcia w ww. uchwałach, w ustawie o utrzymaniu czystości i porządku w gminach oraz w ustawie Prawo budowlane. Nie znaleziono definicji w innych przepisach prawa.

Rozporządzenie w sprawie warunków technicznych, jakim powinny odpowiadać budynki i ich usytuowanie definiuje jedyne pojęcie budynek mieszkalny, którym jest budynek mieszkalny wielorodzinny oraz budynek mieszkalny jednorodzinny [§ 3 pkt 4].

Rozporządzenie Rady Ministrów w sprawie Polskiej Klasyfikacji Obiektów Budowlanych (PKOB) w dziale 11 „Budynki mieszkalne” wyróżnia:

- budynki mieszkalne jednorodzinne - grupa 111;

- $\quad$ budynki o dwóch mieszkaniach i wielomieszkaniowe - grupa 112.

\section{Domek letniskowy}

Brak definicji tego pojęcia w ww. uchwałach, w ustawie o utrzymaniu czystości i porządku w gminach oraz w ustawie Prawo budowlane. Nie znaleziono definicji w innych przepisach prawa.

Należy podkreślić, że:

1) ustawa Prawo budowlane nie zabrania, aby budynek mieszkalny jednorodzinny był traktowany jako domek letniskowy;

2) rozporządzenie Rady Ministrów w sprawie Polskiej Klasyfikacji Obiektów Budowlanych stanowi, że budynki mieszkalne jednorodzinne to m.in. domki wypoczynkowe, domy letnie (dział 11, grupa 111, klasa 1110). 


\section{Nieruchomość wykorzystywana na cele rekreacyjno-wypoczynkowe}

Brak definicji tego pojęcia w ww. uchwałach, w ustawie o utrzymaniu czystości i porządku w gminach oraz $\mathrm{w}$ ustawie Prawo budowlane. Nie znaleziono definicji w innych przepisach prawa.

Jak już napisano, obiekty budowlane w rodzinnych ogrodach działkowych nie są traktowane jak nieruchomości wykorzystywane na cele rekreacyjno-wypoczynkowe, ale jak nieruchomości, na których nie zamieszkują mieszkańcy [art. 6j ust. 3 i 3d ucz].

\section{Dyskryminacja jednoosobowych gospodarstw domowych - w majestacie prawa}

Przyjęte w Warszawie opłaty za gospodarowanie odpadami komunalnymi uderzają w osoby samotne, zwłaszcza w emerytów i rencistów. Jednoosobowe gospodarstwo domowe ma płacić tyle samo, co rodzina złożona z kilku osób.

Według opracowanej przez GUS Prognozy gospodarstw domowych na lata 2016-2050 odsetek jednoosobowych gospodarstw domowych wynosił i będzie wynosił:

- $\quad$ w Polsce: 25,9\% (2016 r.) oraz 31,9 \% (2030 r.);

- $\quad$ w województwie mazowieckim: w przedziale od 24,4\% do 27,4\% (2016 r.) oraz w przedziale od 27,4\% do 30,4\% (2030 r.) [GUS s. 38].

GUS nie dysponuje dokładniejszymi danymi, o czym informuje Pan Piotr Filip, Naczelnik Wydziału Departamentu Badań Demograficznych: „W okresach międzyspisowych nie są prowadzone szacunki liczby gospodarstw domowych. Najbardziej aktualne dane w tym obszarze pochodzą z Narodowego Spisu Powszechnego Ludności i Mieszkań 2011." [e-mail z 06.07.2020 r.].

Na podstawie powyższych informacji można przyjąć, że jednoosobowe gospodarstwa domowe w Warszawie stanowią nie mniej niż 25\% wszystkich gospodarstw domowych. W stolicy mamy 775,5 tysięcy gospodarstw domowych [www.wirtualnemedia.pl - dane z 23.06.2020 r.], co oznacza, że jednoosobowych gospodarstw domowych jest od 190 do 200 tysięcy.

Z posiadanych informacji wynika, że do marca 2020 r. osoby samotne, zamieszkujące lokale w budynkach wielolokalowych, za gospodarowanie odpadami komunalnymi płaciły 10 zł miesięcznie (np. w Dzielnicy Ursynów, w Dzielnicy Ochota, na Nowym Mieście). Obecnie opłata wynosi 65 zł miesięcznie. Różnica 55 zł, w skali roku daje kwotę 660 zł.

Przeciętny miesięczny dochód rozporządzalny na 1 osobę wynosi w 2020 r. - 1819 zł. Emeryci i renciści często nie dysponują nawet i taką kwotą. W formie dodatków do dochodów, w 2020 r. emeryt dostał 980 zł. (tzw. trzynasta emerytura), a rodzice z dwojgiem dzieci dostaną 12000 zł. (z programu 500+) oraz inne dodatki (300+), bon turystyczny.

Gospodarowanie odpadami, to „zbieranie, transport, przetwarzanie odpadów”. Nie trzeba prowadzić badań, aby stwierdzić, że od jednej osoby zbierze się znacznie mniej odpadów, 
niż od czteroosobowej rodziny. Opłaty pobierane od jednoosobowych gospodarstw domowych, zwłaszcza emerytów i rencistów:

1) nie uwzględniają ich możliwości finansowych;

2) nie mogą być uznane za sprawiedliwe, bo dyskryminują tę grupę społeczną.

\section{Wielokrotne pobieranie opłat od tego samego gospodarstwa domowego - naruszenie prawa}

Wydaje się bezspornym, że przepis $\S 1$ uchwały nr XXIV/671/2019 stanowi, iż stawki opłat są ustalane dla gospodarstwa domowego. To gospodarstwo domowe ma wnosić opłaty, których wysokość jest zależna wyłącznie od tego, czy zamieszkuje nieruchomość:

- będącą budynkiem mieszkalnym jednorodzinnym;

- będącą budynkiem mieszkalnym wielolokalowym.

Spotkano się z zupełnie inną interpretacją ww. uchwały, którą omówiono poniżej ku przestrodze. Osoba samotna (jednoosobowe gospodarstwo domowe) jest właścicielem dwóch lokali mieszkalnych, położonych w tym samym budynku wielolokalowym. Deklaruje, że jej miejscem zamieszkania jest jeden z ww. lokali. Drugi stoi pusty, nikt w nim nie mieszka, ale opłaty pobierano od obu lokali: 65 zł + 65 zł = 130 zł miesięcznie. Opisana powyżej sytuacja jest zapewne wyjątkiem, ale wyraźnie wskazuje na brak jednoznaczności prawa, skoro można je zinterpretować w sposób niezwykle krzywdzący dla samotnej osoby.

Opłata 65 zł dotyczy wyłącznie lokalu, w którym zamieszkują mieszkańcy, a za nieruchomości, na których nie zamieszkują mieszkańcy, ustala się opłaty tylko wtedy, gdy powstają tam odpady komunalne.

\section{Domek letniskowy, a nieruchomość, na której nie zamieszkują mieszkańcy - brak jedno- znaczności prawa}

Właściciele domków letniskowych oraz innych nieruchomości wykorzystywanych na cele rekreacyjno-wypoczynkowe mają obowiązek ponoszenia opłat za gospodarowanie odpadami komunalnymi „,za rok bez względu na długość okresu korzystania z nieruchomości” [art. 6i ust. 1 pkt 3 ucz], nawet jeśli nie powstają tam odpady komunalne.

Brak definicji pojęć: domek letniskowy, nieruchomość wykorzystywana na cele rekreacyjno-wypoczynkowe, prowadzi do uznaniowości w ustalaniu opłat. Nie wiadomo jak odróżnić, np.:

1) budynek mieszkalny jednorodzinny, który nie jest niczyim miejscem zamieszkania od domku letniskowego;

2) domek letniskowy, do którego od lat nikt nie przyjeżdża od nieruchomości, na której nie zamieszkują mieszkańcy.

Taki stan prawny skutkuje wielokrotnym pobieraniem opłat od tego samego gospodarstwa domowego - w miejscu zamieszkania i od posiadanej czy posiadanych nieruchomości. 
Nie znaleziono przepisu, który zakazuje właścicielowi domku letniskowego przewozić odpady komunalne powstałe w tym domku, do miejsca gromadzenia odpadów dla budynku, w którym ma miejsce zamieszkania. Jeśli przyjąć, że nie ma takiego zakazu, a właściciel deklaruje, że wywiezie odpady, to pobieranie opłaty od takiej nieruchomości nie powinno mieć miejsca. To tak samo jak zabieranie swoich butelek i opakowań po kanapkach z lasu, w którym się było na spacerze.

Uchwała nr XXIV/671/2019:

1) ustala ryczałtową stawkę w wysokości 169,30 zł za domek letniskowy;

2) za nieruchomości, na których nie zamieszkują mieszkańcy nakazuje opłaty, tylko jeśli powstają tam odpady komunalne;

3) nie precyzuje, jak odróżnić od siebie te dwa rodzaje nieruchomości.

\section{Kto i jakie opłaty ma wnosić - brak jednoznaczności prawa}

\section{Przykład 1}

Osoba samotna (jednoosobowe gospodarstwo domowe) jest właścicielem budynku mieszkalnego jednorodzinnego oraz lokalu mieszkalnego, położonego w budynku wielolokalowym. Deklaruje, że jej miejscem zamieszkania jest ww. lokal mieszkalny oraz płaci miesięcznie $65 \mathrm{zł}$.

Budynek jednorodzinny wynajmuje lokatorowi, np. na rok (najem okazjonalny w rozumieniu ustawy o ochronie praw lokatorów, mieszkaniowym zasobie gminy i o zmianie kodeksu cywilnego). Lokator oświadcza, że jego miejscem zamieszkania jest inny budynek mieszkalny jednorodzinny, położony również w Warszawie (jest tam zameldowany na pobyt stały), ale aktualnie nie może tam przebywać, bo np. prowadzi remont. W miejscu zameldowania płaci 94 zł miesięcznie za gospodarowanie odpadami.

Kto i ile ma płacić za wynajmowany na podstawie ww. umowy najmu budynek mieszkalny jednorodzinny:

- właściciel - dodatkowo 94 zł miesięcznie?

- lokator - dodatkowo 94 zł miesięcznie?

Przykład 2

Rodzina wielopokoleniowa, złożona z dwóch gospodarstw domowych: babcia (jednoosobowe gospodarstwo domowe) oraz syn z żoną (dwuosobowe gospodarstwo domowe), jest właścicielem budynku mieszkalnego jednorodzinnego, w którym są dwa lokale. Wszyscy deklaruja, że ww. nieruchomość jest ich miejscem zamieszkania. Czy mają płacić:

- 94 zł miesięcznie?

- $\quad 94 \mathrm{zł}+94 \mathrm{zł}=188 \mathrm{zł}$ miesięcznie (dwa gospodarstwa domowe)?

- $\quad 65 \mathrm{zł}+65 \mathrm{zł}=130 \mathrm{zł} \mathrm{miesięcznie?}$ 


\section{Podsumowanie}

Przykłady można mnożyć. Wydaje się, że powyższe wystarczają żeby wykazać jak przepisy uchwał podjętych przez Radę m.st. Warszawy:

1) są krzywdzące dla jednoosobowych gospodarstw domowych;

2) są niezrozumiałe, co pozwala na „interpretacje urzędniczą”, nastawioną na to, aby pobrać jak najwięcej pieniędzy.

Kodeks cywilny nie pozostawia wątpliwości - można mieć tylko jedno miejsce zamieszkania [art. 28 Kc]. Opłaty 65 zł i 94 zł miesięcznie dotyczą wyłącznie nieruchomości, które są miejscem zamieszkania gospodarstwa domowego. Nie dotyczą nieruchomości, które są własnością gospodarstwa domowego. Polskie prawo nie zabrania bywania we własnych nieruchomościach, a to, że się $\mathrm{w}$ nich bywa nie oznacza, że się $\mathrm{w}$ nich mieszka, albo że są domkiem letniskowym.

Warszawa stworzyła niebezpieczny precedens - oby, za przykładem stolicy, nie zaczęto naliczać w taki sam sposób opłat za gospodarowanie odpadami w całej Polsce. Usprawiedliwienia dla Władz Warszawy można się jedynie dopatrywać w zbyt skomplikowanych przepisach ustawy o utrzymaniu czystości i porządku w gminach.

\section{Wnioski - proponowane zmiany prawa}

Przy obecnym systemie prawnym, najbardziej sprawiedliwą i akceptowaną społecznie wydaje się metoda naliczania opłat od liczby mieszkańców zamieszkujących daną nieruchomość. Oczywiście metoda ta będzie sprawiedliwa jedynie, jeśli szanowany jest przepis art. 28 Kodeksu cywilnego, który stanowi, co należy powtarzać, że można mieć tylko jedno miejsce zamieszkania. Praktyka wskazuje, iż pojęcie miejsce zamieszkania może być różnie interpretowane, a to prowadzi do podwójnego, czy nawet wielokrotnego naliczania opłat od tego samego gospodarstwa domowego.

Uzależnienie wysokości opłat od ilości zużytej wody z danej nieruchomości powoduje, że najwięcej zapłacą ci, którzy dbają o higienę osobistą. Nie wiadomo, czy naliczać opłaty od wody używanej do podlewania roślin, a wykazanej w założonym do ustalania jej ilości liczniku. Jeśli tak, to wiele osób przestanie pielęgnować ogrody.

Uzależnienie wysokości opłat od powierzchni lokalu mieszkalnego jest wyjątkowo mało precyzyjne. Ustawa o utrzymaniu czystości i porządku w gminach stanowi, że opłata wynosi: „0,08\% przeciętnego miesięcznego dochodu rozporządzalnego na 1 osobę ogółem - za m² powierzchni lokalu mieszkalnego", ale nie ustala o jaką powierzchnię chodzi.

Polski system prawny i normy wyróżniają szereg powierzchni lokali i budynków, np.: powierzchnia całkowita, powierzchnia netto, powierzchnia użytkowa. Należy pamiętać, że budynek mieszkalny jednorodzinny to najczęściej jeden lokal mieszkalny. Powierzchnia użytkowa ww. budynku, w zależności czy obliczana na podstawie ustawy o podatkach i opłatach lokalnych, czy którejś z norm, będzie się różnić. Różnice mogą wynosić nawet kilkadziesiąt metrów kwadratowych. 
Ustalenie jednej stawki opłat dla nieruchomości, na których zamieszkują mieszkańcy maksymalnie 5,6\% przeciętnego miesięcznego dochodu rozporządzalnego na 1 osobę ogółem za gospodarstwo domowe - tylko pozornie wydaje się metodą najprostszą. Powyżej opisane sytuacje (przykłady) wyraźnie pokazują jak jest niedoskonała.

Uzależnianie opłat od liczby zużywanych worków (pojemników) i ich pojemności może prowadzić do wyrzucania śmieci na „dzikie wysypiska”, a w najlepszym razie do ulicznych koszy na śmieci. Należy jednak zaznaczyć, że istnieją opinie, iż takie postępowanie stymuluje zachowania proekologiczne [Carattini, Baranzini, Lalive 2018; Bueno, Valente 2019].

Nie tylko autorzy niniejszego artykułu mają wątpliwości, co do obiektywizmu metod naliczania opłat, przyjętych w ustawie o utrzymaniu czystości i porządku w gminach. „Niektóre z tych czynników, jak np. liczba osób zamieszkujących daną nieruchomość mogła prowadzić do niejednolitej interpretacji stanu zamieszkania. W przypadku dużej migracji z gmin wiejskich i małych miast do większych, wiele osób sporadycznie przebywa w swoich rodzinnych stronach, a zatem nie korzysta z bieżącego wywozu odpadów. Jednakże ceny wywozu odpadów w mniejszych miejscowościach i gminach są niższe w związku z niższym kosztem utrzymaniu wysypisk śmieci, a zatem osoby te $z$ finansowego punktu widzenia były bardziej skłonne do zarejestrowania się do wywozu śmieci w miejscu swojego pierwotnego zamieszkania, aniżeli w miejscu bieżącego zamieszkania. Nie można również wykluczyć podwójnego ujęcia danej osoby, kiedy to jedna gmina przyjmowała miejsce zameldowania jako wyznacznik mieszkańca, a druga faktyczne zamieszkanie. Parametry takie jak powierzchnia nieruchomości czy ilość zużytej wody mają niewątpliwie walor obiektywności pomiaru, choć w dużo mniejszym stopniu są związane z ilością wygenerowanych do wywozu odpadów." [Żurawiecka, Kocia 2019, s. 48 i 49].

Zbyt skomplikowane przepisy ustawy o utrzymaniu czystości i porządku w gminach, nie zachęcają do dbania o czystość miast i wsi. Ustawa nie przewiduje premiowania za prawidłowe gospodarowanie odpadami, a jedynie kary. Grzywna może być wymierzona temu, kto:

1) nie utrzymuje czystości i porządku [art. 10 ust. 2 ucz];

2) nie złożył deklaracji o wysokości opłat [art. 10 ust. 2b];

3) nie kompostuje w posiadanym kompostowniku bioodpadów [art. 10 ust. 2c ucz].

Karanie za błędy w kompostowaniu odpadów, przy uchwalonej w Warszawie obniżce opłat 4 zł miesięcznie, zniechęci mieszkańców domów jednorodzinnych do tego typu czynności. W skali roku maksymalnie zaoszczędzą 48 zł, a narażają się na kontrole, które mogą skutkować wymierzeniem grzywny.

Wszystkie przytoczone powyżej definicje odpadów komunalnych nie pozostawiają wątpliwości - to wytwór ludzi. Najprostszym rozwiązaniem byłoby wprowadzenie jednej opłaty od każdego człowieka deklarującego miejsce zamieszkania na terenie Polski, również od dzieci, bo to one 'tworzą' najwięcej odpadów komunalnych (pieluszki, słoiczki, plastikowe butelki, zabawki na jeden dzień, ubranka, z których się błyskawicznie wyrasta itp.). W praktyce, sprowadziłoby się to do pobierania opłaty od każdego dorosłego, który płaci podatki w Polsce. Przy obecnie obowiązującym systemie podatkowym, ww. opłatę można powiązać np. z podatkiem dochodowym danej osoby, powiększonym o opłatę za dzieci. 
Takie rozwiązanie zlikwidowałoby spory, dotyczące tego:

1) kto gdzie mieszka, ile ma nieruchomości oraz co oznaczają takie pojęcia jak: zamieszkują mieszkańcy czy domek letniskowy;

2) kto i ile wody zużywa oraz jak to szacować;

3) jak ustalać powierzchnie lokali.

Ponadto zlikwidowany zostałby obowiązek składania deklaracji dotyczących wysokości opłat za gospodarowanie odpadami komunalnymi, co przyczyniło by się do zmniejszenia biurokracji oraz produkcji odpadów. Każda deklaracja, to papier.

Proponowany system mógłby również przewidywać ulgi i zwolnienia z opłat dla osób w najtrudniejszej sytuacji ekonomicznej, np. dla seniorów.

Może warto również pomyśleć o przywróceniu np. punktów skupu makulatury. Zapłata za dostarczony papier niewątpliwie przyczyniłaby się do selekcjonowania odpadów.

\section{Literatura}

Bueno M., Valente M., 2019, The effects of pricing waste generation: A synthetic control approach, Journal of Environmental Economics and Management, 96, s. 274-285.

Carattini S., Baranzini A., Lalive R., 2018, Is Taxing Waste a Waste of Time? Evidence from a Supreme Court Decision, Ecological Economics, 148, s. 131-151.

Karaczun Z.M., Indeka L.G., 1996, Ochrona środowiska, Agencja Wydawnicza ARIES, Warszawa.

Kiepas-Kokot A., 2017a, Odpady. Plany gospodarki odpadami. Komentarz, Seria: Komentarze Becka, Warszawa.

Kiepas-Kokot A., 2017b, Odpady. Zezwolenia na zbieranie i przetwarzanie. Komentarz, Seria: Komentarze Becka, Warszawa.

Leonard D., 2003, Przewodnik po Unii Europejskiej (tytuł oryginału Guide to the European Union, przekład z j. angielskiego: A. i W. Matuszyńscy, uaktualnienie: D. Bakalarz), Wydawnictwo Studio EMKA Ltd, Warszawa.

Michałowski S., Jacyna I., Szulczewski M., 1994, Ekologiczne wyzwania Polski. Zagrożenia a świadomość społeczeństwa, Wydawnictwo KOPIA Sp. z o.o., Warszawa.

Mostowska A., Budziński Ł., Wilczyńska J. (red.), 2014, Ustawa o odpadach. Komentarz, Seria: Komentarze Becka, Warszawa.

Niewiadomski Z. (red.), 2019, Planowanie i zagospodarowanie przestrzenne. Komentarz, wydanie 11, Seria: Komentarze Becka, Warszawa.

Nowicki M., 1993, Strategia ekorozwoju Polski, Agencja Reklamowo-Wydawnicza A. Grzegorczyk, Warszawa. 
Potyra M., Waligórska M. (red.) 2016, Prognoza gospodarstw domowych na lata 2016-2050, Departament Badań Demograficznych i Rynku Pracy, Wydział Prognoz Demograficznych, Główny Urząd Statystyczny, Warszawa.

Żurawiecka A., Kocia A., 2019, Najnowsze zmiany w zakresie gospodarki odpadami - analiza prawno-ekonomiczna, MAZOWSZE Studia Regionalne, 31, s. 39-54, DOI:10.21858/MSR.31.02.

\section{Strony Internetowe}

Filip P., Naczelnik Wydziału, Departament Badań Demograficznych GUS - e-mail z 06.07.2020 r.

Strona internetowa GUS [dostęp: 25.06.2020].

Wikipedia [dostęp: 25.06.2020].

www.wirtualnemedia.pl_775,5 tysięcy gospodarstw domowych w Warszawie, duże zróżnicowanie w dzielnicach [dostęp: 23.06.2020].

\section{Źródła prawa}

\section{Ustawy}

Kodeks cywilny z dnia 23 kwietnia 1964 r. (tj. z dnia 16 maja 2019 r., Dz.U. z 2019 r. poz. 1145 z późn. zm.) w skrócie Kc.

Ustawa z dnia 12 stycznia 1991 r. o podatkach i opłatach lokalnych (tj. z dnia 16 maja 2019 r., Dz.U. z 2019 r. poz. 1170 z późn. zm.).

Ustawa z dnia 7 lipca 1994 r. Prawo budowlane (tj. z dnia 21 maja 2019 r., Dz.U. z 2019 r. poz. 1186, z późn. zm.).

Ustawa z dnia 13 września 1996 r. o utrzymaniu czystości i porządku w gminach (tj. z dnia 18 października 2019 r., Dz.U. z 2019 r. poz. 2010 z późn. zm.) w skrócie ucz.

Ustawa z dnia 21 czerwca 2001 r. o dodatkach mieszkaniowych (tj. z dnia 18 października 2019 r., Dz.U. z 2019 r. poz. 2133).

Ustawa z dnia 21 czerwca 2001 r. o ochronie praw lokatorów, mieszkaniowym zasobie gminy i o zmianie Kodeksu cywilnego (tj. z dnia 6 czerwca 2019 r., Dz.U. z 2019 r. poz. 1182 z późn. zm.).

Ustawa z dnia 14 grudnia 2012 r. o odpadach (tj. z dnia 16 kwietnia 2020 r., Dz.U. z 2020 r. poz. 797 z późn. zm.) w skrócie uod. 


\section{Rozporządzenia}

Rozporządzenie Rady Ministrów z dnia 30 grudnia 1999 r. w sprawie Polskiej Klasyfikacji Obiektów Budowlanych (PKOB) (Dz.U. nr 112, poz. 1316 z późn. zm.).

Rozporządzenie Ministra Infrastruktury z dnia 12 kwietnia 2002 r. w sprawie warunków technicznych, jakim powinny odpowiadać budynki i ich usytuowanie (tj. z dnia 8 kwietnia 2019 r., Dz.U. z 2019 r. poz. 1065).

Rozporządzenie Ministra Środowiska z dnia 14 grudnia 2016 r. w sprawie poziomów recyklingu, przygotowania do ponownego użycia i odzysku innymi metodami niektórych frakcji odpadów komunalnych (Dz.U. z 2016 r. poz. 2167).

Rozporządzenie Ministra Środowiska z dnia 29 grudnia 2016 r. w sprawie szczegółowego sposobu selektywnego zbierania wybranych frakcji odpadów (tj. z dnia 7 października 2019 r., Dz.U. z 2019 r. poz. 2028).

\section{Akty prawa miejscowego}

Uchwała nr XXIV/671/2019 Rady m.st. Warszawy z 12 grudnia 2019 r. w sprawie wyboru metody ustalania opłaty za gospodarowanie odpadami komunalnymi, ustalenia stawki takiej opłaty oraz ustalenia stawki opłaty za pojemnik i worek o określonej pojemności (Dz. Urz. Woj. Mazowieckiego z 16 grudnia 2019 r. poz. 15291), w skrócie uchwała nr XXIV/671/2019.

Uchwała nr XXIV/672/2019 Rady m.st. Warszawy z 12 grudnia 2019 r. zmieniająca uchwałę w sprawie określenia terminu, częstotliwości i trybu uiszczania opłaty za gospodarowanie odpadami komunalnymi (Dz. Urz. Woj. Mazowieckiego z 16 grudnia 2019 r. poz. 15292), w skrócie uchwała nr XXIV/672/2019.

Uchwała nr XXIV/676/2019 Rady m.st. Warszawy z 12 grudnia 2019 r. w sprawie ustalania sposobu obliczania opłaty za gospodarowanie odpadami komunalnymi w przypadku nieruchomości, która w części stanowi nieruchomość, na której zamieszkują mieszkańcy, a w części nieruchomość, na której nie zamieszkują mieszkańcy, a powstają odpady komunalne (Dz. Urz. Woj. Mazowieckiego z 16 grudnia 2019 r. poz. 15293), w skrócie uchwała nr XXIV/676/2019.

Uchwała nr XXV/728/2020 Rady m.st. Warszawy z 16 stycznia 2020 r., zmieniająca uchwałę w sprawie wyboru metody ustalania opłaty za gospodarowanie odpadami komunalnymi, ustalenia stawki takiej opłaty oraz ustalenia stawki opłaty za pojemnik i worek o określonej pojemności (Dz. Urz. Woj. Mazowieckiego z 17 stycznia 2020 r. poz. 870), w skrócie uchwała nr XXV/728/2020. 
Uchwała nr XXV/730/2020 Rady m.st. Warszawy z 16 stycznia 2020 r., zmieniająca uchwałę w sprawie ustalania sposobu obliczania opłaty za gospodarowanie odpadami komunalnymi w przypadku nieruchomości, która w części stanowi nieruchomość, na której zamieszkują mieszkańcy, a w części nieruchomość, na której nie zamieszkują mieszkańcy, a powstają odpady komunalne (Dz. Urz. Woj. Mazowieckiego z 17 stycznia 2020 r. poz. 872), w skrócie uchwała nr XXV/730/2020.

Uchwała nr XXV/731/2020 Rady m.st. Warszawy z 16 stycznia 2020 r. w sprawie określenia wzorów deklaracji o wysokości opłaty za gospodarowanie odpadami komunalnymi oraz warunków i trybu składania deklaracji za pomocą środków komunikacji elektronicznej (Dz. Urz. Woj. Mazowieckiego z 30 stycznia 2020 r. poz. 1387), w skrócie uchwała nr XXV/731/2020.

\section{Obwieszczenia i inne dokumenty rządowe}

Obwieszczenie Prezesa Głównego Urzędu Statystycznego z dnia 27 marca 2019 r. w sprawie przeciętnego miesięcznego dochodu rozporządzalnego na 1 osobę ogółem w 2018 r. (M.P. z 2019 r. poz. 278).

Obwieszczenie Prezesa Głównego Urzędu Statystycznego z dnia 31 marca 2020 r. w sprawie przeciętnego miesięcznego dochodu rozporządzalnego na 1 osobę ogółem w 2019 r. (M.P. z 2020 r. poz. 330).

Obwieszczenie Prezydenta m.st. Warszawy w sprawie stawek opłat za gospodarowanie odpadami komunalnymi i wzorów deklaracji z 2020 r.

Mapa Drogowa Transformacji w kierunku gospodarki o obiegu zamkniętym - dokument Rady Ministrów Rzeczypospolitej Polskiej z 2019 r. 


\section{Załącznik - Podstawy prawne podjęcia uchwał decydujących o wysokości opłat za gospodarowanie odpadami komunalnymi w Warszawie}

\section{Uchwała nr XXIV/671/2019}

Uchwała nr XXIV/671/2019 Rady m.st. Warszawy z 12 grudnia 2019 r. w sprawie wyboru metody ustalania opłaty za gospodarowanie odpadami komunalnymi, ustalenia stawki takiej opłaty oraz ustalenia stawki opłaty za pojemnik i worek o określonej pojemności. Uchwała podjęta na podstawie art. 6k ust. 1 pkt 1 i 2 oraz 6 j ust. 2, 3a, 3b ustawy o utrzymaniu czystości i porządku w gminach.

\section{Art. 6k ust. 1 pkt 1 i pkt 2 stanowią:}

„Rada gminy, w drodze uchwały:

1) dokona wyboru metody ustalenia opłaty za gospodarowanie odpadami komunalnymi spośród metod określonych w art. 6j ust. 1 i 2 oraz ustali stawkę takiej opłaty; dopuszcza się stosowanie więcej niż jednej metody ustalenia opłat na obszarze gminy;

2) ustali stawkę opłaty za pojemnik lub worek o określonej pojemności, przeznaczony do zbierania odpadów komunalnych na terenie nieruchomości."

\section{Art. 6j ust. 2 stanowi:}

„W przypadku nieruchomości, o której mowa w art. 6c ust. 1, rada gminy może uchwalić jedną stawkę opłaty za gospodarowanie odpadami komunalnymi od gospodarstwa domowego."

Ww. art. $6 c$ ust. 1 stanowi:

"Gminy są obowiązane do zorganizowania odbierania odpadów komunalnych od właścicieli nieruchomości, na których zamieszkują mieszkańcy."

\section{Art. 6j ust. 3a stanowi:}

„W przypadku nieruchomości, o której mowa w ust. 3, na której są świadczone usługi hotelarskie w rozumieniu art. 3 ust. 1 pkt 8 ustawy z dnia 29 sierpnia 1997 r. o usługach hotelarskich oraz usługach pilotów wycieczek i przewodników turystycznych (Dz.U. z 2019 r. poz. 238), dopuszcza się, aby opłata za gospodarowanie odpadami komunalnymi stanowiła iloczyn ilości zużytej wody z danej nieruchomości oraz stawki opłaty za gospodarowanie odpadami komunalnymi, o której mowa w art. 6k ust. 1 pkt $1 . "$

Ww. art. 6 j ust. 3 stanowi: 
„W przypadku nieruchomości, na której nie zamieszkują mieszkańcy, opłata za gospodarowanie odpadami komunalnymi stanowi iloczyn zadeklarowanej liczby pojemników lub worków, przeznaczonych do zbierania odpadów komunalnych powstających na danej nieruchomości, oraz stawki opłaty za gospodarowanie odpadami komunalnymi, o której mowa w art. $6 \mathrm{k}$ ust. 1 pkt 2."

\section{Art. 6j ust. 3b stanowi:}

„W przypadku nieruchomości, na której znajduje się domek letniskowy, lub innej nieruchomości wykorzystywanej na cele rekreacyjno-wypoczynkowe, rada gminy uchwala ryczałtową stawkę opłaty za gospodarowanie odpadami komunalnymi nie wyższą niż 10\% przeciętnego miesięcznego dochodu rozporządzalnego na 1 osobę ogółem - za rok od nieruchomości, na której znajduje się domek letniskowy, lub od innej nieruchomości wykorzystywanej na cele rekreacyjno-wypoczynkowe."

\section{Uchwała nr XXIV/672/2019}

Uchwała nr XXIV/672/2019 Rady M.st. Warszawy z 12 grudnia 2019 r. zmieniająca uchwałę w sprawie określenia terminu, częstotliwości i trybu uiszczania opłaty za gospodarowanie odpadami komunalnymi.

Uchwała podjęta na podstawie art. 61 ust. 1 ustawy o utrzymaniu czystości i porządku w gminach.

\section{Art. 6 I ust. 1 stanowi:}

„Rada gminy określi, biorąc pod uwagę warunki miejscowe, w drodze uchwały stanowiącej akt prawa miejscowego, termin, częstotliwość i tryb uiszczania opłaty za gospodarowanie odpadami komunalnymi, w tym wskazanie czy opłatę uiszcza się z dołu czy z góry."

\section{Uchwała nr XXIV/676/2019}

Uchwała nr XXIV/676/2019 Rady M.st. Warszawy z 12 grudnia 2019 r. w sprawie ustalania sposobu obliczania opłaty za gospodarowanie odpadami komunalnymi w przypadku nieruchomości, która w części stanowi nieruchomość, na której zamieszkują mieszkańcy, a w części nieruchomość, na której nie zamieszkują mieszkańcy, a powstają odpady komunalne. 
Uchwała podjęta na podstawie art. 6 j ust. 5 oraz art. $6 \mathrm{k}$ ust.1, ust. 3 i ust. 4 ustawy o utrzymaniu czystości i porządku w gminach.

\section{Art. 6j ust. 5 stanowi:}

„W przypadku nieruchomości, o których mowa w ust. 4, rada gminy może podjąć uchwałę stanowiącą akt prawa miejscowego, na mocy której ustali sposób obliczania opłaty za gospodarowanie odpadami komunalnymi na terenie tych nieruchomości zgodnie z ust. 1 , 2 lub 3, z tym że w przypadku ustalenia sposobu obliczania opłaty zgodnie z ust. 1 pkt 3 dla części nieruchomości, na której jest prowadzona działalność, uwzględnia się powierzchnię użytkową lokalu."

\section{Art. 6k ust. 1 - patrz powyżej.}

\section{Art. 6k ust. 3 stanowi:}

„Rada gminy określi stawki opłaty podwyższonej za gospodarowanie odpadami komunalnymi, jeżeli właściciel nieruchomości nie wypełnia obowiązku zbierania odpadów komunalnych w sposób selektywny, wysokości nie niższej niż dwukrotna wysokość i nie wyższej niż czterokrotna wysokość stawki ustalonej przez radę gminy odpowiednio na podstawie ust. 1 albo w art. 6j ust. 3b."

\section{Art. 6k ust. 4 stanowi:}

„Rada gminy, w drodze uchwały, może zwolnić w całości lub w części z opłaty za gospodarowanie odpadami komunalnymi właścicieli nieruchomości, na których zamieszkują mieszkańcy, w części dotyczącej gospodarstw domowych, w których dochód nie przekracza kwoty uprawniającej do świadczeń pieniężnych z pomocy społecznej, o której mowa w art. 8 ust. 1 lub 2 ustawy z dnia 12 marca 2004 r. o pomocy społecznej (Dz.U. z 2019 r. poz. 1507, 1622, 1690 i 1818), lub rodziny wielodzietne, o których mowa w ustawie z dnia 5 grudnia 2014 r. o Karcie Dużej Rodziny (Dz.U. z 2019 r. poz. 1390 i 1907)."

\section{Uchwała nr XXV/728/2020}

Uchwała nr XXV/728/2020 Rady m.st. Warszawy z 16 stycznia 2020 r., zmieniająca uchwałę w sprawie wyboru metody ustalania opłaty za gospodarowanie odpadami komunalnymi, ustalenia stawki takiej opłaty oraz ustalenia stawki opłaty za pojemnik i worek o określonej pojemności. 
Uchwała podjęta na podstawie art. $6 \mathrm{k}$ ust. 1 pkt 1 i 2, ust. 3 i ust. 4 a oraz 6 j ust. 2, 3a, 3b ustawy o utrzymaniu czystości i porządku w gminach.

\section{Art. 6 k ust. 1 pkt 1 i 2 , ust. 3 oraz 6 j ust. 2, 3a, 3b - patrz powyżej.}

\section{Art. 6k ust. 4a stanowi:}

„Rada gminy, w drodze uchwały, zwalnia w części z opłaty za gospodarowanie odpadami komunalnymi właścicieli nieruchomości zabudowanych budynkami mieszkalnymi jednorodzinnymi kompostujących bioodpady stanowiące odpady komunalne $\mathrm{w}$ kompostowniku przydomowym, proporcjonalnie do zmniejszenia kosztów gospodarowania odpadami komunalnymi z gospodarstw domowych."

\section{Uchwała nr XXV/730/2020}

Uchwała nr XXV/730/2020 Rady m.st. Warszawy z 16 stycznia 2020 r., zmieniająca uchwałę w sprawie ustalania sposobu obliczania opłaty za gospodarowanie odpadami komunalnymi w przypadku nieruchomości, która w części stanowi nieruchomość, na której zamieszkują mieszkańcy, a w części nieruchomość, na której nie zamieszkują mieszkańcy, a powstają odpady komunalne.

Uchwała podjęta na podstawie art. $6 \mathrm{j}$ ust. 5 oraz art. $6 \mathrm{k}$ ust.1, ust. 3 i ust. 4 a ustawy o utrzymaniu czystości i porządku w gminach.

Art. 6 j ust. 5 oraz art. $6 \mathrm{k}$ ust. 1 ,ust. 3 i ust. $4 \mathrm{a}$ - patrz powyżej.

\section{Uchwała nr XXV/731/2020}

Uchwała nr XXV/731/2020 Rady m.st. Warszawy z 16 stycznia 2020 r. w sprawie określenia wzorów deklaracji o wysokości opłaty za gospodarowanie odpadami komunalnymi oraz warunków i trybu składania deklaracji za pomocą środków komunikacji elektronicznej.

Uchwała podjęta na podstawie art. 6 n ust. 1 i ust 2 ustawy o utrzymaniu czystości i porządku w gminach. 


\section{Art. 6 n ust. 1 i ust 2 stanowią:}

„1. Rada gminy, uwzględniając konieczność zapewnienia prawidłowego obliczenia wysokości opłaty za gospodarowanie odpadami komunalnymi oraz ułatwienia składania deklaracji, określi, w drodze uchwały stanowiącej akt prawa miejscowego:

1) wzór deklaracji o wysokości opłaty za gospodarowanie odpadami komunalnymi składanej przez właścicieli nieruchomości, z uwzględnieniem art. 6m ust. 1a i 1b, obejmujący objaśnienia dotyczące sposobu jej wypełnienia, informacje wskazane w art. 13 ust. 1 i 2 rozporządzenia Parlamentu Europejskiego i Rady (UE) 2016/679 z dnia 27 kwietnia 2016 r. w sprawie ochrony osób fizycznych w związku z przetwarzaniem danych osobowych i w sprawie swobodnego przepływu takich danych oraz uchylenia dyrektywy 95/46/WE (ogólne rozporządzenie o ochronie danych) (Dz.Urz. UE L 119 z 04.05.2016, s. 1, z późn. zm.) oraz pouczenie, że deklaracja stanowi podstawę do wystawienia tytułu wykonawczego; uchwała zawiera także informację o terminach i miejscu składania deklaracji;

2) warunki i tryb składania deklaracji za pomocą środków komunikacji elektronicznej, w szczególności:

a) ich format elektroniczny oraz układ informacji i powiązań m.in. zgodnie z przepisami o informatyzacji działalności podmiotów realizujących zadania publiczne,

b) sposób ich przesyłania za pomocą środków komunikacji elektronicznej,

c) rodzaje podpisu elektronicznego, którym powinny być opatrzone.

2. Rada gminy w uchwale, o której mowa w ust. 1, może określić wykaz dokumentów potwierdzających dane zawarte w deklaracji o wysokości opłaty za gospodarowanie odpadami komunalnymi." 


\section{Changes in the municipal waste management system - legal and economic aspects as exemplified by the Capital City of Warsaw}

\section{ABSTRACT}

The authors of the article believe that the methods of setting the rates of municipal waste management fees, adopted in the Act on maintaining cleanness and order in municipalites, are overly complex and should be modified. The simplest and the fairest option would be to introduce a single fee for each person declaring their place of residence in Poland. The fee can be linked to, for example, income tax.

Such a solution would eliminate disputes concerning one's place of residence, number of properties, what is meant by such terms as residents or a summer house, how water consumption should be estimated and dwelling area determined.

The example of Warsaw, is used to demonstrate that the municipal waste management system effective from 01.03.2020, determined by the Act on maintaining cleanness and order in the municipalities, is imprecise. In many cases, it is unclear how to calculate fees. The system is detrimental to one-person households, a significant number of which consist of retirees and pensioners.

Key words: municipal waste, principles of municipal waste management, fee rate, household, place of residence 
58 ZMIANY W SYSTEMIE GOSPODARKI ODPADAMI KOMUNALNYMI - ASPEKTY PRAWNE I EKONOMICZNE... Anna Wieczorek, Maciej Siekierski

\begin{abstract}
Anna Wieczorek - na Politechnice Warszawskiej ukończyła Wydział Architektury, Podyplomowe Studium Urbanistyki, Studium Doskonalenia Pedagogicznego oraz uzyskała dyplom doktora nauk technicznych. Posiada uprawnienia do projektowania w planowaniu przestrzennym oraz uprawnienia do pełnienia samodzielnych funkcji technicznych w budownictwie. Specjalizuje się w wykonywaniu projektów miejscowych planów zagospodarowania przestrzennego (główny projektant ponad 30 uchwalonych projektów planów miejscowych) oraz projektów studiów uwarunkowań i kierunków zagospodarowania przestrzennego gmin (główny projektant 5 uchwalonych stdiów). Ma doświadczenie w pracy ze studentami - na Politechnice Warszawskiej i w Wyższej Szkole Przedsiębiorczości i Administracji w Lublinie. Należy do Mazowieckiej Okręgowej Izby Architektów z siedzibq w Warszawie oraz Pan-Europejskiej Federacji Ochrony Zabytków - Europa Nostra z siedzibq̨ w Holandii.

Anna Wieczorek - graduate of the Warsaw University of Technology - Faculty of Architecture, Postgraduate Town Planning Studies, Pedagogical study, PhD in technical science. Holds professional permits for spatial planning and is authorised to perform independent technical functions in construction. Specialises in the preparation of local spatial development plans (is the main designer of more than 30 approved local development plans) and of the studies of conditions and directions of the spatial development of municipalities (main designer of 5 approved studies). Has experience in working with students - at the Warsaw University of Technology and the University College of Enterprise and Administration in Lublin. Member of the Warsaw-based Masovian Chamber of Architects and the Pan-European Federation for Cultural Heritage, Europa Nostra based in the Netherlands.
\end{abstract}

Maciej Siekierski - dr hab. inż. adiunkt w Katedrze Chemii Nieorganicznej Wydziału Chemicznego, autor i współautor prawie 200 publikacji naukowych cytowanych około 500 razy (623 z pominięciem autocytowań 460), (indeks Hirsha równy 9 wg Scribus, 12 według SCOPUS). Ponadto w dorobku istotna część stanowi współautorstwo w ponad 100 wystapieniach konferencyjnych. Około połowy z nich było prezentowane osobiście. Kierownik, główny wykonawca i wykonawca wielu projektów badawczych i dydaktycznych finansowanych przez NCBiR, NCN, KBN, UE, EOG i NATO. Kierownik i wykonawca badań przemysłowych prowadzonych na zlecenie wiodących firm z sektora energetycznego (PSE Operator, ENEA, PGE, PKP PLK). Laureat nagród (Rektora PW i Prezesa Rady Ministrów). Wizytował szereg ośrodków naukowych (Kanada, Niemcy, Francja, Hiszpania). Od poczq̨tku 2019 reprezentuje Wydział Chemiczny Politechniki Warszawskiej w Radzie Klastra Gospodarki Odpadowej i Recyklingu. Od czerwca 2019 roku pełni funkcję przewodniczqcego Rady Ekspertów KGOiR.

Maciej Siekierski - PhD Eng, DSc, Assistant Professor at the Department of Organic Chemistry in the Faculty of Chemistry, author and co-author of almost 200 scientific publications cited about 500 times (623; 460 excluding self-citations), (Hirsch index equal of 9 according to Scribus, 12 according to SCOPUS). Moreover, a significant part of his achievements is the co-authorship of over 100 conference speeches. About half of them were presented in person. Supervisor, main contractor and contractor of many research and didactic projects financed by NCRD, NSC, KBN, EU, EEA and NATO. Supervisor and contractor of industrial research conducted at the request of leading companies in the energy sector (PSE Operator, ENEA, PGE, PKP PLK). Laureate of the Rector of WUT's award and the Prime Minister's award. Visited several research centres (Canada, Germany, France, Spain). Since the beginning of 2019, has been representing the Faculty of Chemistry at the Warsaw University of Technology in the Council of the Waste Management and Recycling Cluster. Since June 2019, holds the position of the Chairman of the Council of Experts in the WMRC. 